\title{
sciendo
}

Research Article

(c) 2019 Nwali et.al..

This is an open access article licensed under the Creative Commons

Attribution-NonCommercial-NoDerivs License (http://creativecommons.org/licenses/by-nc-nd/3.0/).

\section{Privatisation of Public Enterprises in Nigeria: Challenges and Prospects on Economic Development}

\section{Anthony Chukwuma Nwali}

Nwokeiwu Johnson

Bethel Oganezi

Department of Accountancy/Business Administration/Banking and Finance, Federal University Ndufu Alike Ikwo, Ebonyi State, Nigeria

Doi: $10.2478 / \mathrm{mjss}-2019-0059$

\section{Abstract}

Privatisation plays key roles in restructuring economic and social attributes of developing countries. The performance of any economy in terms of growth rate and per capita income have always been based on and associated with active involvement and participation of the private sector. It is apt to note that public enterprises in Nigeria have failed to demonstrate strong desire and ability to promote economic growth perhaps due to ineptitude of the managers and inadequate clear-cut operational guidelines establishing such enterprises. This effort attempts to evaluate the importance and implications of privatisation of government's companies with respect to economic development. The analytical tool adopted in this paper is descriptive that focussed on review and evaluation of privatisation exercise in Nigeria. Findings indicate that corruption, indiscipline, suspicion, transparency and national sovereignty among others were the major challenges of privatisation in Nigeria. Aligning with the new order of moving poor resource utilization to more innovative and creative initiatives orchestrated the call for privatisation in Nigeria in addition to productivity improvement, increase in revenue, reduction in budget deficits as well as elimination of wastes and improvement of efficiency. The paper concludes by advocating for appropriate reform policies of all inclusiveness and transparency that offer full information about the company slated for privatisation and the attributes of core investors to quell misinformed ideas and suspicion.

Keywords: Privatisation, Public Enterprises, Challenges, Opportunities, Economic Development

\section{Introduction}

Privatisation is the transfer of ownership and control of enterprises from the state to the private sector. It is a system of economic and operational restructuring and reallocation of public assets from the public sector to the private sector. (Adnan 2005) asserts that the process is a fundamental economic ideology that promotes ingenuity that can lay claim to property right. This topical issue has drawn intense global debate in recent years especially in developing economies like Nigeria where the organised labour, academia and individuals have criticised the policy on account of transparency. The critics argue that privatisation is capitalist oriented likely to short change the labour force resulting in redundancy, pay-cuts, downsizing, lay-offs and retrenchment to pave way for increase in profit margins of the private investors.

However, the proponents of privatisation opine that privatisation is a global economic reform that promotes efficient management of resources for economic development of the country. Some of these public enterprises had outgrown their utility and therefore the committed and energetic employees of those moribund enterprises who understood the concept of value could transfer their entrepreneurial premise to any private sector. Privatisation is a radical movement of unproductive government enterprises to more efficient relevant private investors with proven records of technical 
know-how (Young and Brodkin 1987). It is a route out of the procedural thicket to corruption. It is a deliberate policy for the main purpose promoting efficiency that informs such decision rather welfare. The sceptics on the other hand are concerned about the uncertainties in the private sector even though they agree that the private sector has more opportunities.

Development in economic term means achieving sustained rate of expansion that is far greater than the growth rate of the population (Todaro and Smith, 2011). In others words, for any economy to tow the path of development, positive change in all the factors of production and people's standard of living must exist. The aims of this paper therefore are to review and clarify the concept of privatisation as an ideological economic reform policy of any government and how such policy impacts on economic development by ensuring that certain enterprises are private-sector-driven.

\subsection{Statement of problem}

Although a sizeable number of studies have been carried out on privatisation of public enterprises and its effect on economic development, only a limited number of such studies have attempted to review the challenges and prospects it has brought to bear on the economic landscape of Nigeria and her teaming population. The main reason for this gap, perhaps, could be that privatisation is a new phenomenon. Privatisation, as an economic reform policy, reduces the inefficiencies of the public sector, provides greater scope to the private sector, attracts more investments and more importantly, revives the ailing productive sectors of the economy through ownership restructuring. This noticed lacuna justifies the present efforts to examine and analyse the challenges and prospects of privatisation which has come to occupy the centre stage in the economic policies of various Nigerian governments.

\subsection{Objectives of the study}

Privatisation has become the new global economic reform policy in recent times perhaps due to its tendency for better contribution in raising the standard of living as an instrument of economic development. In this context therefore, this paper is poised to present a general overview of privatisation programme in Nigeria, the challenges and prospects on economic development of the country.

\subsection{Research Methodology}

The analytical tool adopted in this paper is descriptive that focussed on review and evaluation of privatisation exercise in Nigeria and how such ownership shift - from public to private - has affected the workings of the economy in terms of economic development. The study made use of secondary information to justify discussions and recommendations.

\section{Conceptual Analysis}

\subsection{Privatisation}

Nigeria's education policy and the curricula of most tertiary institutions, attempting to create a superior civil service, placed less emphasis on developing employees but rather, professionals of white-collar job seekers. This formula, undoubtedly, may be a necessary condition for a stable and disciplined society, but not the one that promotes competition and challenges creativity and risktaking. Privatisation requires a substantial change in culture of business operations that seeks to transform public business perspectives to an entrepreneurial society - risk and reward and creation of personal versus collective wealth. In public corporations/enterprises, rules and operating procedures do not always meet customers' unique needs. The concept of privatisation is an idea that has opened a new chapter in the conflict over the public - private balance. It is the process of selling public assets (corporations) to individuals or private business interests. There are as many definitions as the number of authors on the subject. Nwoye (1997) as noted by the Privatisation and 
Commercialisation Act of 1988 and the Bureau of Public Enterprises Act of 1993 submits that is shedding-off in part or whole, government equity holdings in public corporations/enterprises. It is an ideological concept that transfers ownership structure (production, management and control) of the enterprises from public to private sector. It signifies a quasi-withdrawal of interests and relinquishing of such interests to the private hands for purposes of efficiency. Public sector employees do not understand the concept of value creation and not curious on the need to make a difference and this necessitated the call for privatisation unquestionable advantage. Therefore, privatisation, just like in other developing economies, emerged in response to the decline in productivity of public corporations and managerial ineptitude of the operators.

\subsection{Public Enterprises}

The structure of the world's economies is private sector aligned and Nigeria aims to be in tune with this traditional economic pattern. Occasioned by the abundance of natural resources and the need to harness them for economic development, production of goods and services and promotion of welfare to the citizens, public enterprises emerged, (Nwoye, 1997). Public enterprises are business organizations entirely or partly established set up and controlled by the government through the state authority. Starr (1988) argues that the concept of public enterprise implies an elaborate structure of rules through which the state exercises power over the control of the enterprise. The enterprise acts for the society, with its operations openly visible and accessible to all. The idea is to establish an enterprise that equitably distributes essential welfare to the citizens that may be abused if left with the private operators.

\subsection{Economic Development}

Todaro and Smith (2011) define development as an expansion that surpasses the growth rate of the country's population. In other words, the growth rate of income per capita must be faster and sustainable than the population growth. Growth of income per capita is expected to be accompanied by increase in productivity occasioned by the expansion of output. Income per capita is obtained by dividing Gross National Income (GNI) with the total population. Economic development can also be seen as a deliberate effort to increase the productive capacity of both the service and manufacturing sectors of the economy. The central focus of real development is rapid industrialisation at the expense of agriculture and rural development. Until recently, problems of poverty, unemployment, discrimination and income distribution were of less importance to growth issue.

\section{Theoretical Framework}

In the recent decades, privatisation has received global attention making it a new phenomenon in the area of economic policy. Adnan, (2005) reports that the modern idea of privatisation as an economic policy emanated in the Federal Republic of Germany in 1957 when government stakes in Volkswagen were offloaded to private investors. In the 80s, Margaret Thatcher privatised Britain Telecom and in France, Chirac privatised large banks. Similarly, Megginson, Nash and Randenborgh, (1996) observe that Japan and Mexico privatised government owned communication companies to attract efficiency and economic development. Poole, (1996) acknowledges that between 1984 and 1994, the world witnessed tremendous shift in assets ownership from public sector to private sector. With the hope of stimulating economic growth, communist regime in Eastern Europe and former Soviet Union as well as China and Cuba caved in to the wind of privatisation (Adnan 2005). Sanusi, (2001), sees privatisation as attempts to promote competition and removal of barrier to entry through the activities of market forces. In this context, it is the process that increases the population of investors by demonopolizing certain enterprises/corporations in order to encourage private sector driven economy where efficiency, better quality products/services are competitively offered. Similarly, it is also a method of divesting of government interests in the affairs of public enterprises such that the control is in the hands of private investors who will be interested in the efficient operations of the enterprises in order to bring profit and develop the economy which is the core objective of any government and 
business organisation. In Nigeria therefore, efficiency forms the core objective of government keying into privatisation programme.

\subsection{Privatisation and Efficiency Theory}

A major factor in privatisation is to reduce the large size of the existing government interests characterised by unnecessary layers of bureaucracy. Contextually, privatisation implies a paradigm shift to improve efficiency. Private sector is motivated by rewards and ability to allocate scarce resources effectively unlike the public sector that is riddled with inefficiency and seldom has economic goals. Poole, (1996) points out that privatisation redirects the priority of governments from political to economic goals in order to develop a strong and economically viable market economy. Through privatisation, government is restricted to provision of maintenance of attractive environment for private sector to actively participate in economic development and by this, the chances of government meddling with the management of such enterprises that often breed corruption and inefficiency reduces. Reducing the size of the public sector, total expenditure is reduced while revenue is increased through tax generated from the privatised enterprises. This practice according to Poole, (1996) slashes the endemic cycle of over-borrowing that often increases national debt.

\subsection{Privatisation and Property Rights}

One of the most normative theories justifying privatisation is the laissez-faire approach that emphasises individualism and free-market economies. Starr, (1988) observes that laissez-faire system brings greater efficiency, more individual choice and less government intervention if the domain of property rights and market forces are broadened. Right of ownership encompasses many other rights - right to use an asset, alter the form, change location, dilute the substance, or outright transfer of all or some of the rights. The proponent of property rights believes that people are strictly individualistic. This means that the more gain is attached to a property, the more individuals tend to that property. On the other hand, the lower the gains on a property, the less enthusiasm and demonstration of effective and efficient supervision. In private sector, managers may be sacked if the enterprise records low return necessitating the shareholders to shed-off their holdings in the enterprise as a result of inefficiency, slack attention and excessive salaries. In the public sector, Furubotn and Pejovich (1974) in Starr (1988) note that "these crucial deterrents to inefficient management are missing in the public sector" There is no check for the decline in value of public enterprise since the citizens do not have transferable property rights such as selling their stocks to protest weak performance of the enterprise/management.

\subsection{Privatisation and Public Choice Theory}

Public Choice Theory explains that managers of "bureaucratic enterprises" lobby and even bribe to maximise budgets just to obtain greater power, bigger salaries and other benefits associated with their jobs. Consequently, budget maximisation involves increased government spending, padding of agencies' budgets, inefficient production, bribing for political positions among others. Therefore, Public Choice Theory, as equally noted by property rights, indicts public ownership management. Starr, (1988) summaries that in public choice concept, democratic politics have inherent tendencies toward government growth and excessive budgets; self-interest of coalition of voters, politicians and bureaucrats are responsible for expenditure growth; and that public enterprises are less efficient than private enterprises.

\subsection{Privatisation and Coase Theory}

Mankiw (2001) points out that in Coase theorem, individual actively participates in a cost-benefit analysis which invariably produces the most beneficial solution to any problem in the enterprise. The Theory points out that moving the assets of the state to private individuals (privatisation) makes the market more effective and active in handling numerous externalities (Medema, 1999). 


\subsection{Privatisation and Community Empowerment}

This type of privatisation sees efficiency and profitability of operations as the criteria for ownership restructuring of public corporations less important. It is sociologically oriented and it pays attention on empowering the host communities mainly. Berger and Neuhaus (1977) submit that the idea is to strengthen community unions, voluntary and religious organizations, cooperative groups and non formal organizations that are neither individual nor society oriented organizations. While appreciating the position of social welfare, they argued that recognition of mediating instruments for the delivery of publicly financed services is indeed very crucial. Profit motive and expansion were considered less valuable to strengthening local and small-scale interests of social oriented.

\subsection{Types of Privatisation Programmes}

Starr, (1988) submits that privatisation may take any of the following dimensions:

- Implicit privatisation or privatisation by attrition. In this situation, government ceases or disengages itself from public programmes or specific kinds of responsibilities forcing consumers to shift to private sources. Government in this case makes investment climate conducive for private participation while gradually disengaging/withdrawing itself from the investment web of that sector.

- Explicit privatisation. This involves sale or lease of public land, infrastructure/public assets to private ownership through policy pronouncement backed up by appropriate state legislation.

- Contracting out/Vouchers. This type allows government to finance private services instead of direct involvement. It could be referred to as partial privatisation because of governments' indirect and limited involvement in the management of the enterprise.

- Deregulation of Entry. Government may decide to liberalise entry into certain activities that it previously treated as public monopolies.

These spectrum of alternatives run from total to partial privatisation. Privatisation may include policies anywhere along these spectrum, the implication and its contribution to economic growth vary with its degree. The different techniques used to privatise public assets determine what emerges as privatisation. This is because all these variations in the policy make the effect privatisation has on performance of the economy very difficult to determine.

\subsection{Public perception and application of privatisation}

Contextually and practically, the application of privatisation is a function of economic status of the country in the global economy. In richer and more developed countries, privatisation is purely regarded as a domestic policy; but in a foreign dominated core investors (buyers) noticeably in under-developed economies, privatising government companies often denotes de-nationalisation (Starr, 1988). Poole (1996) notes that prior to late 1970 s and 1980 s, privatisation was not a viable economic restructuring policy.

One major reason for the emergence of state owned enterprises has always been nationally oriented-self-assertion hence privatisation to foreign investors may undermine national pride, honour and sovereignty of the country. Starr, (1988) in this context observes that when a country's investment hub is controlled by foreign investors, there are greater chances of foreigners taking over the entire privatised companies and such undermines the country's sovereignty and pride of nationalism. Privatisation may not receive state attention if the dominance of foreign investors threatens the country's sovereignty and security most especially if such enterprises have strategic military or economic significance. Marshall, (1987) notes that in-spite of America's free market economic policy, the Regan Administration in 1987, stopped the sale of a private American Semi-conductor Company with important defence contracts to a Japanese corporation. Similarly, the same administration privatised American Space Industry perhaps, for competitive reasons. These steps were taken by the administration simply not to jeopardise America's interest and sovereignty. Therefore, the relative power and position of a given state in the world economy defines the degree of conflict between privatisation and national interests (the weaker the country, the more likely the conflict). 
Similarly, suspicion of political, racial, religion and ethnic/regional dominance captures the feelings of minorities on issues of privatisation programmes. Privatisation may be politically resisted and understood as a transfer of wealth and power from one group to another if the country's political, administrative structure and major entrepreneurial class differ in ethnic composition and regional participation. Equally, genuine, realistic and efficient-oriented privatisation may elude if the society is polarised along ethnic/religious divide and the enterprises to be sold are not equitably distributed along ethnic/geopolitical lines.

Privatisation, especially in developing economy such as Nigeria is mainly inefficiency focussed. Mankiw (2001) posits that efficiency remains an indicator of privatisation, but in developing countries, political arrangement plays crucial roles. In some countries, especially the developed ones, public management is well established which encourages continuity and growth whereas in other countries such as Nigeria, the political party that formed the government uses such position to appreciate political allies/loafer, relations and close associates. This pattern undermines professionalism, efficiency and breeds corruption at the expense of national interests and economic development. On this basis, the collapse of state owned enterprises are aligned more to poor and weak political structure with little regard for constitutional provision regarding public policy. Institutional devices such as independent governing boards serve to insulate public organisations from political intervention (Kuttner, 1994).

\subsection{Demand-driven privatisation}

In this case, a shift may result not only from a deliberate government action but when certain needs from individual/corporate bodies are not provided by public enterprises due to stagnation or slow growth in the public sector. In this regard, environmental societal forces may compel privatisation to take place. However, Nigeria's experience has been more of policy predominant than demand oriented.

\subsection{Privatisation as a Re-ordering of Claims}

Privatisation needs to be understood as a fundamental re-ordering of claims in a society, (Starr, 1988). The terms, private and public sum up a whole structure of rules and expectations on the limits and proper conducts of each sector in a liberal economy. The essence of this categorisation public, for instance, is to isolate operational structure. De Alessi, (1987) asserts that the concept of property right is the re-assignment of ownership but that there should be greater information disclosure needed to improve the social capacity to participate and make selection that are in harmony with the societal values and ling term interests. However, the distributive implications of re-ordering of claims are the removal of income, wealth and power to those that can apply it in the markets competitively.

\subsection{Evolution of Public Enterprises in Nigeria}

Asaolu, Oyesanmi, Oladele and Oladoyin (2005) report that Decree 25 of 1988 and amended in 1999 legally supported the establishment of Technical Committee for Privatisation and Commercialisation (TCPC) to commence altering ownership re-structuring of government owned enterprises in favour of private participation and possible ownership/take over. The history of public enterprises in Nigeria can be traced to the Colonial government who established these enterprises for provision of essential services such as roads, railways, electricity, telecommunications and other services that may require huge capital out lay. Ake(1981) reports that at the initial stage government was involved in certain aspects of enterprise activities that ordinarily are private sector driven.

Ake, (1981) further notes that this practice continued and four factors were responsible for the growth of public enterprises in the post- colonial era.

- The desire to create Petit-bourgeoisie class. The country's leaders that inherited political power from the colonial rulers needed to skew economic base in order to hold on to power. They used the instrumentality of the office to empower themselves economically through 
appointing their cronies as Board members of those public enterprises to siphon funds from the enterprises to their private ventures.

- The struggle to control the economy and gain economic independence. Public enterprises in Nigeria were established to compete with the foreign ones. The enormous capital requirements orchestrated the setting up of state-owned- enterprises at least to conserve foreign exchange.

- The desire to raise indigenous experts: One other important factor for establishing public enterprises was to train more Nigerians technically aimed at becoming economically independent and the realisation of import substitution.

- The desire to nationalise foreign-owned-private enterprises. Struggling to gain and promote economic independence, the indigenisation policy transferred the ownership of private enterprises to the state.

Other factors include, but not limited to, development emphasis, political considerations as government is evaluated on the basis of provision of certain basic amenities, spreading of certain services/facilities to almost all the nooks and crannies of the state, consumer protection and security of the country.

\subsection{Factors that facilitated the call for privatisation in Nigeria}

Privatisation as stated earlier is the transfer of ownership of production and control of enterprises from the public to the private sector. The obvious reason for this shift of ownership structure are to relocate economic functions for economic development as it became evident that public enterprises are irredeemably inefficient. As a policy that leads to other structural changes in the economy, its focus was to respond to the deteriorating economic conditions and the downturn in the socioeconomic development of Nigeria. These factors are also in tandem with the submissions of Starr (1988), Furubotn and Pejovich (1974), Mankiw (2001), Medema (1999) and Poole (1996). Other factors include:

- Politics of international organisations such as International Monetary Fund as conditions for economic assistance. For instance, debt relief and debt forgiveness obtained under Chief Olusegun Obasanjo's administration from IMF and World Bank were based on the seriousness with which the government pursued privatisation programme as a process of economic reform.

- Higher capacity utilisation to maximise market rewards to realise enterprise goals. This increases efficiency by redirecting the focus of government and delineating political from economic goals thereby strengthening the role of private sector in investment promotion and economic development. As a tool for economic adjustment rather than radical reconstruction, privatisation empowers the community most especially the host community where the enterprise is located for entrepreneurial development.

- Deflects and reduces demands on the government revenue and by this approach, it reduces budget deficit by breaking up the kind of public spending coalitions. By this shift, corruption through the ambitions of board members, government interference and unnecessary skimming for political positions are eliminated thereby restoring the confidence of foreign investor and attracting new technologies.

- Privatisation of wealth. In this regard, it increases ownership and competition under conditions of demand and supply forces will be enhanced. Decline in the value and operational efficiency of the enterprise are progressively checked in private sector management.

\subsection{Privatisation Exercise, 1999 - 2010}

Amaefula (2009), notes that the Bureau for Public Enterprises (BPE) within the few years of President Musa Yar' Adua's administration, realised N4.27bn (four billion, two hundred and seven million naira only) as proceeds from privatisation deals. In 2004, 2005 and 2006, transactions involving 7, 45 and 39 enterprises yielded N50.11bn (fifty billion, eleven million naira only), N98.08bn (ninety eight billion, eight million naira only and N134.74bn (one hundred and thirty four billion, seventy four million naira only), respectively. In 2000, the sale of 6 companies brought an 
income of N14.65bn (fourteen billion, sixty five million naira only) into the coffers of the Federal Government while N12.14bn (twelve billion, fourteen million naira only) was realised from 11 transactions in 2001. Amaefula (2009) further observes that in 2008, Nigerian Newspaper Manufacturing Company, Oku-bokun, Akwa-lbom State was sold to Nigeria Holdings for $\$ 32.5 \mathrm{~m}$ (thirty two million, five hundred thousand dollars only) while Osogbo Steel Rolling Company Limited was privatised to Dangote Group of Companies at a ridiculous price of N2.6bn (two billion, six hundred thousand naira only). From this empirical analysis, it shows that for the period in question, the government realised about N316.59bn (three hundred and sixteen billion, fifty nine million naira only) and $\$ 32.5 \mathrm{~m}$ (thirty two million, five hundred thousand dollars only) from series of privatisation deals. Barring corruption, this amount supposedly was injected into other areas of the economy. In the works of Obadan, (1993), enhancement of efficiency was the primary objective of privatisation programme because maximum efficiency will bring more sustained gains that can be distributed to other segments of the society/economy.

\subsection{New Economic view of Development}

This new era heralded the clamour for more direct attacks on wide-spread absolute poverty, increasing inequitable income distributions and increasing unemployment. Sears (1969) argues that a decrease in all those economic development indicators stabilizes the economy to provide adequate living standard. On the contrary, a decline in any or all is sufficient evidence of underdevelopment. Gross National Income (GNI) growth rates of most developing countries in the 1980s and 90s was abyss and due to rising foreign debt repayment burden, most governments became afraid to cut-down some of their already limited social and economic programmes. A sizeable proportion of these cuts were recorded in privatisation programme hurriedly carried out. This new approach captures development as encompassing changes in the behavioural pattern and national institutions deliberately directed towards inequality reduction and poverty eradication (Todaro and Smith, 2011). In this scenario, development represents a change from the hopeless state of life to a life regarded as materially and spiritually better; a life full of hope and aspirations.

\section{Development Challenges of Privatisation in Nigeria}

The Bureau for Public Enterprises (BPE) has been dynamic in its activities to both local and foreign investors since 1999. The cardinal objective of privatisation is to transform Nigeria into privatesector driven economy where the government will only regulate and concentrate on the art of governance. But the exercise has been controversial, generating strong debates in developing countries where it is believed to have numerous negative impacts. The proponents, like the Efficiency Theory, Coase Theory, Property Rights Theory among others see privatisation as the most effective way of encouraging competition and challenging economic growth while the critics strongly argue that it increases poverty, unemployment and prices of essential goods/services. The anti-privatisation also submits that it is a breach of the fundamental human rights of the workers and outright neglect of the objectives establishing those enterprises and a derogatory way of government reneging on its social responsibilities.

The collapse of the oil market/prices and the global economic recession worsened the performance of the public sector enterprises in Nigeria as the economic pressure could no longer sustain the demands of public enterprises and agencies. With high external debt obligations, unemployment, dearth of foreign exchange and the global drop of oil prices; the main source of Nigeria's revenue, sustenance of these public enterprises became practically impossible. The reformatory nature of privatisation curbs public sector inefficiency, attracts both local and foreign investments, ushers in new technologies, revives the economy and records tremendous growth but with accompanying challenges of mass retrenchment and transfer of public property to few individuals who probably got enriched through looting of the public treasury. From the review, specific challenges of privatisation on economic development are highlighted as follows:

- Corruption, Indiscipline and suspicion. Privatisation is a paradigm shift aimed at improving efficiency of the privatised enterprises but corruption has marred this exercise in Nigeria. Corruption in Nigeria has passed the alarming and entered the fatal stage. Achebe (2012) 
notes that World Bank Report indicates that since independence in 1960, about $\$ 40$ billion has been pilfered from the Country's treasury by the ruling class. This figure ( $\$ 40$ billion) according to Achebe (2012) is approximately the gross domestic products of Norway and Sweden. Most enterprises privatised since 2005 are yet to commence operations probably because they were sold to incompetent investors and/or political loafers. Osogbo Steel Rolling Mill in Osun state privatised to a Philanthropist in 2005 as at the time of this review, is yet to commence operations. This agrees with the submissions of Ramanadham (1994) who pointed out that if criteria for selection of candidates for divestiture are not clearly stated, the state may risk the chances of obtaining reasonable value from the privatised enterprise. He noted further that where deviation from the laid down criteria becomes necessary, the circumstances justifying such deviations must be made known appropriately to allay the suspicion of self-interest.

- Transparency. In most countries, this is a common element and widely alleged to be missing in privatisation policy. Ramanadham (1994) observed that the sale of Thulhiriya Mills to Kabool Lanka Ltd, a South Korean firm in SriLanka and Buhari Hotel lacked transparent transactions. It was also alleged that in Guyana, the National Paint Company was privatised to Guyanese living in Unites States of America under instalment conditions as against better offers from other investors. Privatisation in Nigeria has been abysmally handled, lacking in transparency and riddled with irregularities. Information on the full profile of the core investor(s), terms of agreement and other relevant issues were not adequately provided nor brought to the glare of public knowledge. The activities of our leaders and those saddled with the responsibilities of privatisation have displayed greed, amassing enormous wealth from the exercise. This has compelled some Nigerians to question the genuineness of privatisation programme.

- Privatisation jeopardises and undermines national economic sovereignty. Sovereignty of the country is compromised most especially in situations where foreign investors predominate in the companies privatised. On this note, Starr (1988) observes that foreigninvestor-dependent privatisation is likely to diminish the prospects of the nation's sovereignty. Therefore, nationalism is liable to derail or distort privatisation plans.

- Problems of attracting viable investors. In a polarised political system like Nigeria, politically dominant ethnic groups dominate domestic buyers of public assets at the expense of the minorities who may be better equipped with managerial and technically skills. For instance, people from the Eastern part of the country who abinitio were marginalised in sitting these enterprises slated for privatisation, were uncomfortable and sceptical about investing outside their region given their experiences with their investments in other parts of the country. This fear became justifiable following the recent "quit the north" on or before $1^{\text {st }}$ October, 2017 notice by the Arewa Youths to the Igbo in the North. This declaration was followed by anti-lgbo song with abuses and name calling of the Igbo and a threat to seize all investments belonging to the Igbo in the North. In this case, the field of potential buyers becomes restricted that expected gains from more efficient and skilful investors evaporate. These align with the submissions of Ramanadham (1994) who argues that carefully elicited responses should be sought in fine-tuning of privatisation policies and processes in order to create healthy impression of carrying the entire citizenry along because ethnic considerations and regional disparities may jeopardise local strategic investors from participating.

- Privatising to political allies. Except where the incumbent government has strong desire for transparency, gains of privatisation may be sacrificed in the effort to satisfy the incumbent politicians, bureaucrats, allies and supporters. There is every tendency to compromise the avowed efficiency objectives. These are in agreement with the submission of Helene (1988) who points out that government commonly offers assets and enterprises for sale to political allies for either future political patronage or rewards for previous support.

- Frustration. Umah, (2013), notes that one of the governors in the South Eastern part of Nigeria was alleged to have collected N1bn (one billion naira only) from an industrialists to 
frustrate Ibeto's investment in cement. This investment atrocity and rubbery were committed to pave way for the industrialist to control the cement industry in Nigeria. He further stated that in the 1980s, an industrialist in consortium with a former military head of state banned the importation of rice only to grant the same industrialist the exclusive right to import same products resulting in losses from farmers who obtained credit facilities to set up rice farms.

- Pricing: One of the most thorny and grey areas in privatisation exercise is the price at which the enterprises are sold. Ramanadham (1994) argues that the British Airways Shares and Rover; Rotiplant at Faisalabad and Shahtaj Textiles in Pakintan and Thulhiriya Mills; Buhari Hotel and Ceylon Oxygen in Sri Lanka represented under-pricing. He also stated that Guyana, the National Timber Company was sold for 9.7 million pounds to a foreign investor who after few months resold it for 60 million pounds. In the same vein, Umah, (2013), reports that between 2000 and 2011, in consortium with Chief Olusegun Obasanjo, Dangote purchased government enterprises with most of them under-valued.

As an instrument of political class, privatisation however should be understood as a fundamental re-ordering of claims in a society. It is a global phenomenon characterised by selfish and deceitfully coined objectives (Starr, 1988). In this vein, the perceived irrelevance of the peculiar nature of the society in privatisation exercise will always pose serious challenges to the expected gains of privatisation.

\subsection{Development Prospects of Privatisation}

Globally, privatisation is an avenue to pull out of economic imbalances. In this context, privatisation turns public tenants into private homeowners, private employees and investors. Specifically, privatisation offers the following prospects for development:

- It leads to improved performance as the private sector seems more efficient and more productive. This implies that more jobs are created to expand the scope of the economy and poverty is reduced. On this note, Adnan (2005) submits that given the level of property rights, individuals are more motivated and tend to increase their investments because of the attached direct rewards. It equally encourages healthy competition as private investors take advantage of the free-market economy to maximise their operations. Cook and Uchida (2003) argue that privatisation increases direct foreign investment which is a strong indicator of economic development. It redirects wealth, income and power to those who can more readily exercise it competitively in the market. It redirects aspirations and encourages more entrepreneurial consciousness. Poole (1996) remarks that in spite of the under-developed financial market, Jamaica successfully privatised its National Commercial Bank and it increased the number of shareholders to five times, placing the country's largest bank in the hands of private investors that have better managerial skills and entrepreneurial mind-set to respond to market conditions.

- It increases government revenues, reduces budget deficits, eliminates waste and unnecessary bureaucracy as well as public finance crises. This aligns with the view of Easterly, (2001) who opines that by privatising, the role of government in economic activities are reduced, bad government policies that breed corruption and impact on the negative growth of the economy are totally eliminated. It equally creates needed revenue not meant to finance new government expenditures, pay off future debts, but rather an opportunity to settle existing debts in order to reduce interest rates and increase the level of investment (Adnan, 2005).

- It raises funds for financing social-economic development in areas such as health, education and infrastructure. Privatisation is a step towards re-focussing operations of government enterprises. It fights the ugly trend that government enterprises are nobody's property and as a result, should be looted. World Bank (2002) submits that privatisation ushers in foreign investors with better managerial skills, spill-over of improved technology and access to global production net-work. These opportunities in conjunction with multinational organisations contributions from manufacturing and extractive industries are expected to increase revenue to sponsor health and education sectors for instance. 
However, the study noted corruption/suspicion, transparency, desire to sustain national sovereignty, attraction of foreign investors, sale to political allies, frustration, poor pricing and interferences from international organisations as challenges while improvement in performance, increase in revenues, reduction in budget deficits, elimination of waste/unnecessary bureaucracy and provision of funds to finance socio-economic sectors such as health and education as the development prospects of privatising public enterprises in Nigeria:

\section{Conclusion}

Privatisation, from the foregoing, is an effort to alter the structure of public enterprises to make them more efficient and more result-oriented for economic development. It is also an attempt to reform the ailing Nigeria's public enterprises and prevent them from total extinction. It is equally seen as a major timely needed economic adjustment directed towards efficiency. From the theoretical analysis, incentives play a significant role in the potential success of privatisation as a factor of economic growth (Easterly, 2001). Specifically, privatisation the world-over is a paradigm shift from public to private-sector-driven economy especially if accompanied by appropriate structural reforms. It creates incentives to improve economic efficiency, new technologies are adopted and investments promoted. Consequently, there will be investment opportunities and better favourable climate for enterprises to operate. Privatisation not only increases the status and population of investors/shareholders, it also enhances the performance of the country's stock exchange and growth rate of GDP. Although privatisation endangers and diminishes the status of the country's sovereignty (Starr, 1988) most especially if the economy is dominated by foreign investors and major economic policies determined by international organisations such IMF and World Bank, the gains have the potentials of re-organising the economy if transparency in the exercise is brought to bear. It brings fiscal relief, particularly where the treasury has heavily subsidized unprofitable enterprises. One thing is generally paramount in privatisation policy and which forms the final 'epiphany' of this study; creation of a new understanding.

\subsection{Way forward}

Considering the enormous prospects of privatisation, it is important and expedient too that for further exercises to gain support, succeed and develop the economy as expected, certain steps should be taken. However, privatisation alone, as a fairly recent economic policy aimed at promoting economic growth, may not provide solution to the elusive quest for economic growth and development. Corruption/suspicion, transparency, quest for national sovereignty, attraction of foreign investors, sales to political allies, frustration and poor pricing challenge the gains of privatisation. The study recommends that privatisation should be accompanied by appropriate legal instruments for the structural reforms; guided by transparency that offers full facts about the core investor so as to eliminate misinformed ideas and allegations of corruption to prevent suspicion.

Adequate reforms should be provided to align with the concept of more competitive/friendly market policy as change in ownership structure alone is a micro-economic factor that is not encompassing to guarantee greater enterprise efficiency. Regulatory bodies should also be strengthened to check the entrepreneurial activities of foreign investors so that the sovereignty of the state is not undermined. Government must recognise ethnic polarisation and regional disparities and equally bring labour organisations into all issues involving the exercise. In allocating shares, workers of the privatised enterprises should take the greater percentage because of their preeminent position. In situations where some workers must be retrenched, their entitlements should be settled fully to avoid sabotage.

However, given the enormity of the socio-economic problems of Nigeria, privatisation should be carried out with all forms of sincerity of purpose and honesty, involving all the stake holders especially the labour force who bears the effect directly. Agreed, the policy provides incentives to investors, opens-up the economy, reduces unemployment through expansion of the economy, provides better goods/services, improves government revenue generation through substantial subsidy removal, develops and expands specialised market system; government should evolve 
policies of dealing with the enumerated challenges of privatisation so that a greater level of development that underscores the reasons for the exercise is attained.

\subsection{Contribution to Knowledge}

The study contributes to knowledge as it was conducted in a unique context of analysing the importance of privatisation, the accompanying shortcomings and its effect on economic development. Readers were also reminded that apart from efficiency privatisation driven by demand, involves empowering the community, firm entry deregulation or policy oriented.

\section{References}

Achebe, C. (2012): There was a Country. A Personal History of Biafra, Penguin books Itd, London, pp 249 - 250 Adnan, F. (2005): Impact of Privatisation of Economic Growth: Issues in Political Economy, vol. 14 pp 1, Furman University

Amaefula, E. (2009): Privatisation: BPE Records on deals under Yar' Adua, the Punch News paper, pp 7

Asaolu, T .O.;Oyesanmi, O.; Oladele P.O. and Oladoyin, A.M.(2005): Privatisation and Commercialisation in Nigeria: Implications and Prospects for good governance. South African Journal of Business Management; Sept 2005, Vol. 36, Issue 3, 65

Berger \& Neuhaus, R. (1977). To Empower People: The Role of Mediating Structure in Public Policy in Starr, P. (1988): The Meaning of Privatisation: Yale Law and Policy Review 6:6 - 41[Online] Available: http//www.princeton.edu.

Cook, P. \& Uchida, Y. (2003): Privatisation and Economic Growth in Developing Countries. The Journal of Development Studies, Vol. 39, N0 6, August 2003: 121-1543

De Alessi (1987): Property Rights and Privatisation. 36 Proc. Academy of Political Science Journal 2(4)

Easterly, W. (2001): The Elusive Quest for Growth; MIT Press, Cambridge, Massachusette, U.S.A.

Furubotu, E. \& Pejorich, S. (1974): The Economics of Property Rights. [Online] Available: https://www/Princeton.ed

Glade, W. (1987): Sources and forms of Privatisation in state shrinking: A Comparative Inquiry into privatisation Helen, P. (1988): Privatisation Success in Developed and Developing Countries. Princeton University, U.S.A.

Kuttner, R. (1994): The Economic Illusion: False choices between Prosperity and Social Justice, J. Pub

Mankiw, N.G. (2001): The Essentials of Economics, $2^{\text {nd }}$ Ed. U.S.A.

Marshall, C. (1987): Copter Firm's Bail-out splits British Cabinet, L.A. Times

Medema, S.G. \& Zerbe, R.O. (1999): The Coase Theorem. Encyclopedia of Law and Economics, 839 - 892

Megginson, W.L., Nash, R.C. and Randenborgh, M.V. (1996): The Financial Operational Performance of Newly Privatised Firm: An International Empirical Analysis: The Privatisation Process; Ed Terry L. Anderson and Peter J. Hill. United States of America: Rowman and Littlefield Pub, Inc. 113 - 160.

Nwoye, I. (1997): Privatisation of Public Enterprises in Nigeria. The Views and Counterviews N.I.M., Nigeria.

Obadan, M.I. (1993): Wither Structural Adjustment in Nigeria, Ibadan; NCEMA Monograph Series No. 3.

Poole, R.W. (1996): Privatisation for Economic Development. The privatisation process Ed. Terry L. Anderson \& Peter J. Hill, U.S. Rowman \& Littlefield Pub; Inc.

Ramanadham V.V. (1999): Privatisation and After: Monitoring and privatisation Regulation. Routledge, London, EC4P 4E.

Rempel \& Walters (1987): The Fairchild Deal: Trade War: When Chips were Down, L.A. Times, Nov. 30, 1987, [section] 1, pt. 1 at 1, col. 4.

Savas, E.S. (1987): Privatisation: The key to better government 3; Pearson Educ. Ltd, England

Seers, D. (1969): "The Meaning of Development". Paper presented at the $11^{\text {th }}$ World Conference of the Society for Institute Development, New Delhi, India

Starr, P.(1988): The Meaning of Privatisation: Yale Law and Policy Review 6: 6 - 41 [Online] Available: http//www.princeton.edu.

Stirbock, C. (2005): Success of Privatisation in Impact of Privatisation of Economic Growth: Issues in Political Economy, vol. 14 pp 1 [Online] Available: https://www.princeton.ed

The Concept and Purpose of Public Enterprise: [Online] Available: http://www.britannica.com/topic/public enterprise

Todaro, M.P. and Smith, S.C. (2011): Economic Development. $11^{\text {th }}$ Ed. Pearson Education Ltd, Essex Cm20 2JE, England, pp 14

Umah, I.G. (2013): Elechi versus Ibeto: Facts of the matter (II): Citizen's Advocate Newspaper, June, 23, pp.14. World Bank (1994): World Development Report, 1994 Infrastructure for Development, Washington, D.C.

Young, D.C. and Brodkin, S. (1987): The Political Economy of Privatisation Singapore. 